help feeling that shipowners in their own interests would adopt a wise course by supplying correct data, and otherwise considering the question of framing rules, based on sound principles, which would take cognisance of all the surrounding elements affecting this complex q'xestion, and thereby enable rules and tables to be framed which would be accepted as a fair compromise, and equitable and sound reference fo: the future guidance of all interested in this important subject, and the result of which would, without doubt, tend to diminish the loss of much valuable property and the sacrifice of many human lives."

Messrs. Read and Jenkins, of Lloyd's Register, contribute a valuable investigation into the transverse strains of iron ships. This subject uas, we believe, first investigated vigorously by $\mathrm{Mr}$. W. John, who read a paper on the same subject in 1877 , before the Institution of Naval Architects. The method of treatment pursued by Messrs. Read and Jenkins is too technical to reproduce at length in these pages. After investigating the strains of foir steam-vessels, supposed to be docked when loadef with cargo of the density of coal, up to the height of the lowest tier of beams, they conclude with the important observation that the results demonstrate, in an unmistakable manner, how necessary it is to provide additional transverse strengthening in the engine and boiler space in steam-vessels, where the localised weights of the engines and boilers, and the want of support from the deck above, due to the small number of beams, increase the strain of the middle line and bilge.

The most interesting of the remaining papers were two by Mr. T. Harvard Biles, naval architect to Messrs. J. and G. Thompson, of Glasgow, on Progressive Speed Trials, and on the Curves of Stability of Certain Mail Steamers. The former paper was of great practical value to naval architects, as it affords to all the means of carrying out progressive trials with ease and rapidity. Mr. Biles abandons the measured mile trial, because of the inseparable inaccuracies which attende 1 it. These were due to the varying and unknown rate at which the tide flows, and to the impossibility of knowing whether the ship, when she comes on the mile, is running at her proper speed, or is accelerating her own motion. Mr. Biles throws out from the bow of the ship a floating object which is observed as it passes a a set of transverse sights fixed on the ship about one hundred feet from the bow, and again when it passes another pair of sights fixed at a given distance from the first pair. The time occupied in the transit is recorded by an electric apparatus, which also at the same time records seconds automatically, and also the number of revolutions of the engine. The floating object moves with the tide, and therefore the speed of flow of the latter need not be taken into account. By means of this apparatus, builders can measure the true speed at which their vessels are travelling when steaming right ahead, and consequently can derive all the information to be obtained from progressive trials, without resorting to the oldfashioned, tedious system of runs on the measured mile.

We regret that want of space prevents us from noticing the remaining papers read at these meetings, not one of which was deficient in interest.

\section{NEW AND VERY RARE FISH FROM THE MEDITERRANEAN}

$\mathrm{N}^{\mathrm{N}}$ a long ichthyological excursion which I undertook by order of the Minister of Public Instruction in November and December last, during which I explored our Adriatic coast from Ancona to Lecce, the Ionian shores from Taranto to Reggio (Calabria), and visited the two seas of Sicily, collecting principally at Messina, Catania, and Palermo; I collected above 2000 specimens of fish, amongst which were many rare species, and several quite new to the ichthyofauna of the Mediterranean. Amongst the latter I may mention a large and perfect specimen of Molva vulgaris, fou id in the market of Catania; this is a North Atlantic species, and has not yet been recorded from the Mediterranean; there has been, it is true, for many years a dried skin specimen in the Genoa University Museum, which was figured in 1864 by Canestrini as Haloporphyrus lepidion, and six years afterwards corrected by the same author as Lota vulgaris. About a year ago Dr. Vinciguerra and myself determined it correctly, but as no data as to its capture had been preserved, we were in considerable doubt as to its being a Mediterranean specimen. At Palermo, where I went after leaving Catania, I found a third Italian spezimen of this species. At Messina I collected two specimens of Scorpona ustulati, Lowe, aud a fine specimen of Umbrina ronchus, Val,, both new, to our fauna. I believe that most of the Madeira species will eventually be found in the Mediterranean, especially off the Sicilian coasts. Messina is a splendid locality for deep-sea or pelagic forms; it appears that during stormy weather, especially from the south-east, many abyssal species are in some way thrown up, and may be found in hundreds floating in the Messina harbour, which stretches like a net or trap across the Straits; such are Chauliodus, Stomias, Argyropelecus, Microstoma, Coccia, Maurolicus, Gonostoma, and some ten or twelve species of Scopelus. While there last November I secured a fine Malacocephalus lavis, and a singular fish of a deep black colour, with small eyes and a naked skin, and a most abyssal physiognomy, which is quite new to me, and which I have not yet been able to determine; it may be allied to Malacosteus.

I shall close these notes by mentioning the capture of a very strange fish (belongins to the singular Notacanthi), which may well be called the rarest of fishes. It is a small specimen evidently closely allied to Notacanthus Rissocmus, De Filip, but which appears to present some notable differences; I have not yet been able to compare it with the unique and type specimen of $N$. Rissoanus, from Nice, now in the Turin Zoological Museum, and of which no scientific description was ever published. My specimen was also caught near Nice in August of last year. $N$. Rissoanus should be generically distinguished from the other known species from which it differs in many essential characiers. Lütken and I believe Günther have expressed the same opinion. I should, therefore, propose the name Paradoxichthys, and should that term be pre-occupied, the equivalent Teratichthys. Should the specimen I have turn out specifically distinat from $P$. Rissoanus, I should like to call it Parad $x$ xichthys Garibaldianus, dedicating it to a great Nizzardo and fellow-countryman of Risso.
Flor nce, March 23
Henry H. Giglioli

\section{PROF. BARFF'S NEW ANTISEPTIC}

$\mathrm{I} \mathrm{N}$ a communication to the Society of Arts, March 29, 1882, a long and interesting paper was read by Prof. Barff on a "New Antiseptic Compound" applicable to the preservation of articies of food.

The compound in question is an ether of boric acid and glycerine of the composition $\mathrm{BO}_{3} \mathrm{C}_{3} \mathrm{H}_{5}$ (the chemical description in the paper is inaccurate), first obtained by Schiff and Becchi (Compt. Rendus, 62, p. 397, and J.pr. chem., 98, 184!. Experiments made with this substance on various articles of food, both solid and liquid, seem to have yielded very satisfactory results, as far as the preserving action is concerned; but neither in the paper nor in the interesting discussion which followed its reading does it appear that the preserving action is due specially to the compound in question, or to one of its constituents.

That boric acid acts as a preventive of decomposition in organised bodies when present in considerable quantity there is no doubt, but very little is known of its action in 
those cases, and practically nothing is known of its action on the human economy, especially when taken in the considerable doses that would be contained in the substances preserved by this proposed compound. So that it seems at least desirable that a little more inquiry should be made as to the physiological action of boron compounds before it is proposed as a wholesale preserver of food stuffs.

Of the other constituent of this compound something more is known. It exists naturally in many articles of food or drink, and its physiological action has been to a considerable extent investigated, and proved to be on the whole quite harmless.

As a preservative against fermentive or bacterial action, it has also been investigated more fully than boric acid.

In a concentrated condition it will resist both ordinary fermentation and the fermentation of various bacteria in a high dęree.

As the compound $\mathrm{BO}^{3} \mathrm{C}_{3} \mathrm{H}_{5}$ is decomposed into boric hydrate and glycerine on contact with water, it would scarcely appear that there is any advantage in forming the etherial compound.

It would appear indeed that all the preservative effects claimed for this ether can be obtained by the use of glycerine alone, thus excluding a possible source of danger in the use of a comparatively unknown substance (physiologically) like boric acid (see Kletzinsky, Dingl. pol.J., I7I, 370 ; Kunatb, ibid., I93, 439 ; Wagner, Jahresb., I868, 523 ; Fleck, Dingl. pol. J., 196, 487).

\section{NOTES}

$\mathrm{WE}$ are pleased to learn that the Imperial Government has granted a sum of $2500 l$. (I $500 l$. this year, and $1000 l$. next), and that the Canadian Government has further voted $\$ 4000$ for a station for circumpolar observations.

In the discussion on the New Code, on Monday night, in the House of Commons, Sir John Lubbock pointed out several of its weak points as regards the teaching of science. He complained that children of the fourth standard were excluded from sfecific subjects, and that, as at present worded, children who take class subjects, might never be taught any science at all, as one of them must be English, and another might be history. It would certainly be disappointing, if, after so much thought had been expended in drawing up the New Code, the evident desire of $j$ ts tramers to encourage science teaching should have been defeated. Mr. Maskelyne, Lord G. Hamilton, and others, while supporting Sir John Lubbock's criticisms, pointed out other defects, which, we hope, will have Mr. Mundella's attention. Indeed, he promised to take the suggestions made into consideration, and, we believe, that if he does so seriously, he will see it to be advisable so to frame the regulations as to class and special subjects as to secure that the elements of natural knowledge will have a chance of becoming a regular part of elementary education. The old bugbear attached to the name "elementary science," and to scientific terminology, was alluded to again, but that is a bugbear long ago dissolved, and not worth a moment's consideration; by all who have given the matter any attention, or who have had any experience in teaching, it is admitted that nothing is more interesting to children of all ages than "object lessons," i.e. prac. tical instruction in science, and nothing more dreary and unprofitable than "grammar" as usually taught. Our New Code as it stands is a contrast, so far as science is concerned, to the Primary Education Act of France, which has just been promulgated. The Primary Education which is compulsory in France comprises "Moral and civil instruction, reading, writing, geography, history, some notions of law and political economy, the elements of natural, physical, and mathematical science, their applications to agriculture, health, industrial arts, manual labour, and the use of the tools of the principal crafts, the elements of drawing, modelling, and music, gymnastics, for boys military drill, for girls needlew ork." We shall doubtless reach this standard some day, and one step to it would be to make attendance at school compulsory on all up to the age of fourteen years.

Dr. NaChTigal, the well-known African explorer, has been appointed German Consul in Tunis.

M. PAul Bert was on Monday elected a Member of the Paris Academy of Sciences, in the Medical Section.

THE directors of the Crystal Palace have appointed the following twenty-one British jurymen for the International Electric Exhibition:-Capt. Abney, R.E., F.R.S., Prof. W. Grylls Adams, F.R.S., Major R. F. Armstrong, R.E., Prof. W. E. Ayrton, F.R.S., Mr. Shelford Bidwell, Sir S. Canning, Prof. R. B, Clifton, M.A., F.R.S., Mr. T. R. Crampton, C.E., Mr. Horace Darwin, Prof. G. Carey Foster, F.R.S., Prof. E. Frankland, F.R.S., Capt. Douglas Galton, C.B., F.R.S., Lieut.-Col. W. Haywood, Dr. J. Hopkinson, F.R.S., Prof. D. E. Hughes, F.R.S., Prof. Fleeming Jenkin, F.R.S., Prof. J. W. Keats, Mr. W. H. Preece, F R.S., Prof. Silvanus Thompson, B.A., D.Sc., Mr. C. E. Spagnoletti, C.E., and Lieut.-Col. Webber, R.E., president, Society of Telegraph Engineers.

THE present season seems to have been as remarkably early and open in the Arctic regions as it has been with ourselves. The captain of the French steamer St. Germain reports having encountered an ice-floe of vast extent during his last outward voyage across the Atlantic. During the night of February 24.5 the vessel passed through two fields of ice estimated at from two to three miles in width. On the following morring there lay in the course of the ship an immense agglomeration of masses of ice, many of which resembled the dibris of shattered icebergs, to which no limit could be seen west, north, or south. At this time the vessel was in lat. $46^{\circ} \mathrm{N}$, and long. $50^{\circ} \mathrm{W}$. The ice was drifting from north to south, and for two hours the ship steamed in a southerly direction along the eastern side of the icefloe, at full speed, without seeing any opening, its eastern face being perfectly level. Soon after eight o'clock a channel about two miles wide, and running north and south, opened out, which the captain entered, hoping to reach the open sea to the south, but after about an hour's steaming the channel narrowed into a deep strait, when he decided to continue bis course slowly and push through the ice, and after three hours perilous navigation, saw open water to the west, which he at last entered in lat. $44^{\circ} \mathrm{N}$., and long. $5 \mathrm{I}^{\circ} \mathrm{W}$., or about $\mathrm{I} 20$ miles to the south, and 60 miles to the west of the point at which the ice-floe was first encountered. Even then the southern limit of the floe could not be seen, although the atmosphere was exceptionally clear at the time. Another report informs us that during the Jatter half of March quite a hundred icebergs were seen off Cape Race.

FRoy Nottingham is reported the death this week, at the age of seventy-nine years, of Mr. Sydney Smith, the inventor of the steam-pressure gauge, and many other important engineering appliances. Mr. Smiı was a native of Derby, and was educated at Repton Grammar School. By the invention of the steampressure gauge in 1847 his name became widely known in the engineering world.

THE death is announced of Mr. William Menelaus, a gentleman well-known and highly esteemed in connection with the iron and steel industries of this country. He was in the sixty-fourth year of his age. Mr. Menelaus was past president of the Iron and Steel Institute, of which he was one of the first members. He was also the founder of the South Wales Institute of Engineers. 